\title{
Effect of sea buckthorn juice addition on the oxidative stability, physicochemical and sensory properties of soy milk mayonnaise during refrigerated storage
}

\author{
Violeta Nour
}

\author{
University of Craiova, Craiova, Romania
}

\begin{tabular}{|c|c|}
\hline & Abstract \\
\hline Keywords: & $\begin{array}{l}\text { Introduction. The purpose of the present study was to investigate } \\
\text { the antioxidant potential of the sea buckthorn juice and to explore for }\end{array}$ \\
\hline Mayonnaise & its use as enrichment to soy milk mayonnaise, in order to improve \\
\hline Storage & the color, oxidative stability and sensory quality of mayonnaise \\
\hline Sea buckthorn & during storage. \\
\hline Oxidative & Materials and methods. Four different mayonnaise formulations \\
\hline Physicochemical & were prepared: MC (control), MBHT (made with $0.1 \%$ BHT \\
\hline & $\begin{array}{l}\text { addition), MSB3 (made with } 3 \% \text { sea buckthorn juice addition) and } \\
\text { MSB6 (made with } 6 \% \text { sea buckthorn juice addition). Titratable } \\
\text { acidity, pH, CIELab color values, peroxide values (PV), }\end{array}$ \\
\hline Article history: & $\begin{array}{l}\text { thiobarbituric acid reactive substances (TBARS) values and sensory } \\
\text { attributes were determined in mayonnaise samples immediately after } \\
\text { preparation and at two weeks intervals during the eight weeks storage }\end{array}$ \\
\hline Rece & period. \\
\hline
\end{tabular}

Results and discussion. Sea buckthorn juice had an average Received in revised form 15.05.2021

Accepted

16.07.2021 ascorbic acid content of $78.85 \mathrm{mg} / 100 \mathrm{~g}$ and an average total carotenoid content of $14.66 \mathrm{mg} / 100 \mathrm{~g}$. The addition of the sea buckthorn juice resulted in the increase in redness ( $\mathrm{a}^{*}$ values) as well as the decrease in lightness ( $\mathrm{L}^{*}$ values) and yellowness ( $\mathrm{b}^{*}$ values) of mayonnaise as compared with the control samples. During storage, the redness slightly increased in all the mayonnaise samples, while lightness decreased. The oxidative stability of the mayonnaises was improved through storage by enrichment with sea buckthorn juice,

Corresponding author:

Violeta Nour

E-mail:

vionor@yahoo.com

DOI:

$10.24263 / 2310-$

1008-2021-9-1-3 as indicated by PV and TBARS values. After 8 weeks of storage, PV and TBARS values of MSB3 (12.45 meq $\mathrm{kg}^{-1}$ and $1.35 \mathrm{mg} \cdot \mathrm{kg}^{-1}$, respectively) and MSB6 (12.80 meq. $\mathrm{kg}^{-1}$ and $1.87 \mathrm{mg} \cdot \mathrm{kg}^{-1}$, respectively) were significantly lower compared to control sample (34.20 meq. $\mathrm{kg}^{-1}$ and $2.18 \mathrm{mg} \cdot \mathrm{kg}^{-1}$, respectively), indicating the protective effect of antioxidants from seabuckthorn juice against lipid oxidation in mayonnaise. Except for color, the sensory attributes of mayonnaise were not significantly $(p<0.05)$ affected by the addition of sea buckthorn juice. In terms of color, the highest score was recorded for MSB3 sample throughout the storage period. A syneresis was observed in the last three weeks of the storage period in the samples with added sea buckthorn juice, stronger in samples with $6 \%$ addition.

Conclusions. The improved oxidative stability and sensory properties of the mayonnaise samples obtained with 3\% sea buckthorn juice addition demonstrate the potential of the sea buckthorn juice to be added in mayonnaise for industrial purpose. 


\section{Introduction}

Mayonnaise is a semisolid low-pH oil-in-water $(\mathrm{O} / \mathrm{W})$ emulsion made of the dispersed phase represented by the oil (70-80\%), the aqueous phase containing various components such as $\mathrm{NaCl}$, sugar, mustard, lemon juice or vinegar, and the emulsifier at the interface [1,2]. Owing to its high emulsifying capacity and sesory attributes, egg yolk is the most widely utilized emulsifying agent in mayonnaise [3,4]. However, egg yolk is an animal protein source containing several allergens and one of the most important dietary sources of cholesterol $[5,6]$.

The consumption of mayonnaise has been increasing worldwide but health consciousness regarding this food product, due to its high cholesterol and fat content, have shifted the demand of consumers towards more healthier mayonnaise-like emulsions [7]. As a result, different attempts have been carried out to use another emulsifier in addition to egg yolk, or to completely replace this key ingredient in order to develop low cholesterol sauces with similar characteristics to real mayonnaise $[3,8]$. During the last years, an array of plant proteins (e.g. proteins from soy, sunflower, pea, tomato seed, wheat, white lupin and faba bean) have been tested to stabilize oil-in-water emulsions and to reformulate mayonnaise in order to meet consumer demands $[4,7,9]$. Vegan mayonnaise is the most tested product in studies on the effectiveness of vegetable ingredients to substitute the egg's properties [9]. Soy contains high quality proteins, essential fatty acids and beneficial compounds for human health (i.e. isoflavones, folic acid and polyunsaturated fatty acids) but is low in cholesterol and saturated fat. It provides functional physical properties within food systems and a wide range of health benefits, such as reducing the risk of heart disease, reducing breast cancer risk, slowing or preventing the progression of several cancers and alleviating menopausal symptoms $[10,11]$.

Söderberg [12] investigated the potential of soy protein as egg replacer in vegan foods and found that soy protein has nutritional and emulsifying properties that are similar to that of egg protein. Puppo et al. [13] evaluated the feasibility of replacing common emulsifiers with soy protein isolates in low-calorie salad dressings while Garcia et al. [14] studied the influence of powdered soy milk as an emulsifier to obtain a dressing-type mayonnaise.

The drawbacks with using soy proteins in foods are their content of anti-nutritional factors that negatively affect their digestibility and their distinct "beany" flavor due to the content in saponins, ketones and aldehyde compounds, that may contribute to a reduced consumer acceptance for food products [9].

Mayonnaise, like other high-oil containing foodstuffs, is susceptible to lipid oxidation resulting in the formation of free radicals $(\mathrm{R} \cdot)$, lipid peroxyl radicals $(\mathrm{ROO} \cdot)$ and hydroperoxides $(\mathrm{ROOH})$ as primary oxidation products. Further, the hydroperoxides decompose to aldehydes, ketones, alcohols, hydrocarbons, volatile organic acids and epoxy compounds, known as secondary oxidation products, which are responsible for undesirable off-flavours of the oil $[2,15]$ and consequently decrease the shelf life of mayonnaise [16]. The lipid oxidation reactions are generally initiated at the interface between the oil and water phases, where pro-oxidants can react with the hydroperoxides located at the surface of the oil droplets [17]. Synthetic antioxidants such as butylated hydroxytoluene (BHT), butylated hydroxyanisole (BHA) and ethylene diamine tetraacetic acid (EDTA) are widely used in mayonnaise to prevent rancidity. Although synthetic antioxidants are more effective at low doses, naturally occurring antioxidants may replace synthetic antioxidants in some cases because they are generally recognized as safe [18]. In addition, these compounds could also have health-promoting benefits which may be desirable for consumers $[2,4]$. 
Sea buckthorn (Hippophaë rhamnoides L.) is a deciduous spiny shrub widely distributed in various regions of Asia, Europe and North America, that produces orange, red or yellow berries, and has substantial agricultural, ecological, nutritional, medicinal and ornamental value $[19,20]$. Sea buckthorn berries are the most important part of the plant, being traditionally known for their nutritional and medicinal value. The use of sea buckthorn berries as a natural food ingredient is increasingly gaining popularity nowadays due to their nutraceutical properties and high antioxidant contents [20,21].

Juice extracted from sea buckthorn fruits provides a nutritious beverage, very high in natural antioxidants, especially in ascorbic acid, carotenoids, tocopherols, and flavonoids [20]. It contains also other nutrients and bioactive substances including vitamins, omega-3 fatty acids, free amino acids, dietary minerals, $\beta$-sitosterol and polyphenolic acids [22,23].

The objective of this study was to evaluate the addition of sea buckthorn juice in soy milk mayonnaise for improving its oxidative stability during storage for up to 8 weeks. The effect of sea buckthorn juice on the color parameters and sensory characteristics of prepared mayonnaise were also studied.

\section{Materials and methods}

\section{Sea buckthorn juice}

Fresh sea buckthorn fruits were purchased from a local market in Craiova, Dolj county, South-West Romania. The fruits were frozen and stored in $-20^{\circ} \mathrm{C}$ until use. The frozen seabuckthorn berries were washed, thawed to room temperature and hand-crushed. The juice was pressed out using a conventional juice press and filtered through sterile gauze to remove residual impurities.

\section{Materials and chemicals}

All ingredients used to prepare the mayonnaise, such as refined sunflower oil, soy milk, salt, lemon juice, and mustard were purchased from a local supermarket in Craiova, SouthWest Romania. Butylated hydroxytoluene (BHT), thiobarbituric acid, potassium persulfate, trichloracetic acid, 6-hydroxy-2,5,7,8-tetramethylchroman-2-carboxylic acid (Trolox) and malondialdehyde were obtained from Sigma-Aldrich (St. Louis, Missouri, USA). All other chemicals used were of analytical grade and purchased from Merck (Darmstadt, Germany).

\section{Preparation of mayonnaise}

The control recipe contained the following ingredients in percentage $(\mathrm{w} / \mathrm{w})$ : soy milk 30.8 , sunflower oil 61.5 , salt 1.5 , mustard 3.1 and lemon juice 3.1 . The mayonnaise was made in a one-step procedure. All the ingredients were mixed together for $2 \mathrm{~min}$, using a standard mixer (Moulinex, DFC3, France). Through this formulation, a mayonnaise product with stable emulsion and whithout syneresis was produced.

Four different mayonnaise formulations were prepared: MC (control), MBHT (made with $0.1 \%$ BHT addition), MSB3 (made with 3\% sea buckthorn juice addition) and MSB6 (made with 6\% sea buckthorn juice addition). The sea buckthorn juice was added along with the other ingredients. Mayonnaise samples were packed in $500 \mathrm{ml}$ disposable plastic containers, wrapped externally with aluminum foil to exclude light, and stored in refrigerator $\left(4{ }^{\circ} \mathrm{C}\right)$ for eight weeks. Three different batches for each formulation were prepared. 
Titratable acidity (TA), CIELab color values, peroxide values (PV), thiobarbituric acid reactive substances (TBARS) and sensory attributes were determined in mayonnaise samples immediately after preparation and at two weeks intervals during the storage period (8 weeks).

\section{Total carotenoid content}

Total carotenoid content of the sea buckthorn juice was determined spectrophotometrically as described by Lee [24], with some modifications. The juice samples ( $1 \mathrm{~g})$ were dissolved in $25 \mathrm{ml}$ of $\mathrm{n}$-hexane-acetone-ethanol (v/v/v: 50:25:25) and placed on a shaker at $200 \mathrm{rpm}$ at room temperature. After $10 \mathrm{~min}$, the mixture was centrifuged at $4500 \mathrm{~g}$ for $5 \mathrm{~min}$. The supernatant was collected and made to a volume of $25 \mathrm{~mL}$ with hexane. The absorbance of the hexane extract was read at $450 \mathrm{~nm}$ against $\mathrm{n}$-hexane using a Cary $50 \mathrm{UV}$ spectrophotometer (Varian, Palo Alto, CA, USA). A calibration curve of $\beta$-carotene standard solutions in n-hexane $(0-100 \mathrm{mg} / \mathrm{L})$ was used to determine the carotenoid content of the juice. The total carotenoid content was expressed as milligrams of $\beta$-carotene per 100 grams of juice.

\section{juice \\ Total soluble solids, titratable acidity and ascorbic acid content of sea buckthorn}

The total soluble solids content was determined with a digital refractometer (Hanna Instruments, HI 96801, Romania) and the results were expressed in percentages. Titratable acidity was measured by the titrimetric method and the results were expressed as $\%$ malic acid.

The ascorbic acid content was determined using the iodometric titration [25].

\section{pH measurement}

$\mathrm{pH}$ values of mayonnaise samples were measured at $20{ }^{\circ} \mathrm{C}$ with a Hanna $\mathrm{pH}$ meter HI255 (Hanna Instruments, Padova, Italy) using a 10\% dispersion of mayonnaise in distilled water.

\section{Titratable acidity}

Titratable acidity (TA) of mayonnaise samples was determined by titration method using $0.1 \mathrm{~N} \mathrm{NaOH}$ using phenolphthalein (1\% in 95\% ethanol) as an endpoint indicator. Results were converted to percentage of acetic acid according to AOAC method 935.57 [26].

\section{Peroxide value}

Peroxide value was determined as follows: $5 \mathrm{~g}$ of sample was dissolved in $30 \mathrm{~mL}$ chloroform: acetic acid $(1: 2, \mathrm{v} / \mathrm{v})$ in a conical flask. When the sample was completely dissolved, $0.5 \mathrm{ml}$ of saturated potassium iodide solution was added. After standing for $1 \mathrm{~min}$ in dark, $50 \mathrm{~mL}$ of distilled water and 3 drops of $10 \%$ starch solution were added. The liberated iodine was titrated with $0.1 \mathrm{~N}$ sodium thiosulphate until the solution turn colorless. The blank sample was prepared without the addition of oil sample, and peroxide value was calculated based on equation below:

$$
(\mathrm{S}-\mathrm{B}) \times \mathrm{f} \times \mathrm{N} \times 1000 / \mathrm{W}
$$


where $\mathrm{S}$ - volume of sodium thiosulfate 0.1 used in sample titration, $\mathrm{mL}, \mathrm{B}$ - volume of sodium thiosulfate 0.1 used in blank titration, $\mathrm{mL}, \mathrm{f}-$ factor of sodium thiosulfate solution, dimensionless, $\mathrm{N}$ - normality of sodium thiosulfate solution, dimensionless, $\mathrm{W}=$ weight of oil sample, $\mathrm{g}$.

Peroxide value was expressed as milliequivalents of active oxygen per kilogram of sample.

\section{Thiobarbituric acid reactive substances values}

TBARS values were determined spectrophotometrically as described by Witte et al. [27] with slight modifications. For extraction, five grams of mayonnaise sample were homogenised in a vortex with $12.5 \mathrm{ml}$ of $20 \%$ trichloroacetic acid then transferred to a 25 $\mathrm{ml}$ volumetric flask and dilluted up to the volume with cold distilled water. After filtration, $5 \mathrm{ml}$ of filtrate were mixed with $5 \mathrm{ml}$ of $0.02 \mathrm{M}$ 2-thiobarbituric acid and heated at $100{ }^{\circ} \mathrm{C}$ for $35 \mathrm{~min}$. After cooling, the absorbance was recorded at $532 \mathrm{~nm}$ with a Cary $50 \mathrm{UV}$ spectrophotometer (Varian, Palo Alto, CA, USA). The results were calculated from the standard curve of 1,1,3,3-tetraethoxypropane and expressed as milligrams of malondialdehyde (MDA) per kilogram of sample.

\section{Color measurement}

The color of mayonnaise samples was evaluated by measuring the $\mathrm{L}^{*}$ (lightness), $\mathrm{a}^{*}$ (redness/greenness), and $\mathrm{b}^{*}$ (yellowness/blueness) parameters of the CIEL ${ }^{*} \mathrm{a}^{*} \mathrm{~b}^{*}$ system using a PCECSM1 colorimeter calibrated against a white standard. The analysis was performed on three samples from each formulation with five readings for each sample.

\section{Sensory evaluation}

Sensory evaluation was conducted on the mayonnaise samples after preparation as well as at two weeks intervals during the storage period ( 8 weeks) by ten panelists consisting of graduate students and staff members of the Department of Food Science and Technology, University of Craiova. The test was performed on a nine-point hedonic scale, with $1=$ extremely dislike and $9=$ extremely like. The sample presentation order was randomized and water was provided between samples to cleanse the palate. Before each session, the panelists were trained on each attribute, the hedonic scale used, and what they need to consider during the evaluation.

\section{Statistical analysis}

All experiments were run in triplicate and results are reported as mean \pm standard deviation. In order to assess the effects of formulations and storage time, data were subjected to the analysis of variance (ANOVA) and Duncan's multiple-range test $(\mathrm{P}<0.05)$ using Statgraphics Centurion XVI software (Statgraphics Technologies, Warrenton, USA). 


\section{Results and discussion}

\section{Compositional characteristics of sea buckthorn juice}

The directly squeezed sea-buckthorn juice had a sour-sweet and astringent taste and a smell similar to that of the fresh berries. As observed in a previous study, the juice was turbid as a result of the presence of both insoluble solids and oil droplets suspended in the aqueous juice [28]. Titratable acidity, soluble solids content, ascorbic acid content and total carotenoid content of sea-buckthorn juice are presented in Table 1. The variety, maturity, growing location, climate and method of extraction are the main factors affecting the chemical composition of sea buckthorn berries. Large variations in concentrations of acids have been reported in previous studies, but all agreed that malic acid is the dominant organic acid in sea buckthorn juice $[29,30]$. An average titratable acidity of $7.85 \%$ was found in our study, in good agreement with the results previously reported by Beveridge et al. [29], but much lower than the results reported by Seglina et al. [31]. A large variation in content of soluble solids has been reported in previous studies $(9.3-22.74 \%)$ and it was attributed mainly to the seasonal variation of composition [29]. An average soluble solids content of $9.32 \%$ was found in our study, in good agreement with the results reported by Seglina et al. [31].

Table 1

Titratable acidity, soluble solids content, ascorbic acid content and total carotenoid content of sea-buckthorn juice

\begin{tabular}{|l|c|}
\hline & $\begin{array}{c}\text { Sea buckthorn } \\
\text { juice }\end{array}$ \\
\hline Titratable acidity (\% as citric acid) & $7.85 \pm 0.35$ \\
\hline Soluble solids $(\%)$ & $9.32 \pm 0.24$ \\
\hline Ascorbic acid content $(\mathrm{mg} / 100 \mathrm{~g})$ & $98.85 \pm 3.24$ \\
\hline Total carotenoid content $(\mathrm{mg} / 100 \mathrm{~g})$ & $14.66 \pm 0.56$ \\
\hline
\end{tabular}

Sea buckthorn juice is a valuable source of antioxidants, and vitamin $\mathrm{C}$ is the dominant antioxidant [20]. The average ascorbic acid content found in the sea buckthorn juice used in this study was $98.85 \mathrm{mg} / 100 \mathrm{~g}$. Previous studies revealed extensive variations in vitamin C content, ranging from 28 to $310 \mathrm{mg} / 100 \mathrm{~g}$ in the berries from the European subspecies of $H$. rhamnoides [20,32]. The sea buckthorn juice had an intense orange color due to its high total carotenoid content $(14.66 \mathrm{mg} / 100 \mathrm{~g})$.

\section{CIELab color values of mayonnaise}

BHT determined a significant decrease in yellowness ( $b^{*}$ value) of mayonnaise samples while the addition of sea buckthorn juice resulted in the increase in redness (a* value) as well as the decrease in lightness and yellowness of mayonnaise as compared with the control samples. Similar results have been reported by Altunkaya et al. [33] in a study on the oxidative stability and chemical safety of mayonnaise enriched with grape seed extract. MSB6 samples presented the highest $\mathrm{a}^{*}$ values followed by MSB3 samples, while no significant differences were found between the $\mathrm{a}^{*}$ values of MC and MBHT samples. The increase of the redness in MSB3 and MSB6 samples might be due to the high content of carotenoid pigments in the sea buckthorn juice. 
Changes in lightness $\left(\mathrm{L}^{*}\right)$, redness $\left(\mathrm{a}^{*}\right)$, and yellowness $\left(\mathrm{b}^{*}\right)$ of mayonnaise samples during 8 weeks storage at $4^{\circ} \mathrm{C}$ are shown in Table 2 . The redness slightly increased during storage in all the mayonnaise samples, while lightness decreased. At the end of storage, MSB6 samples recorded the highest $a^{*}$ values and the lowest L* values, followed by MSB3 samples.

Table 2

Effect of storage on CIELab color values of mayonnaise samples

\begin{tabular}{|l|c|c|c|c|}
\hline Time (weeks) & MC & MBHT & MSB3 & MSB6 \\
\hline \multicolumn{5}{|c|}{ L $^{*}$} \\
\hline 0 & $85.22 \pm 0.71^{\mathrm{aC}}$ & $85.81 \pm 0.87^{\mathrm{abB}}$ & $86.83 \pm 0.11^{\mathrm{cC}}$ & $86.54 \pm 0.62^{\mathrm{bcC}}$ \\
\hline 2 & $82.84 \pm 1.77^{\mathrm{A}}$ & $84.34 \pm 0.91^{\mathrm{A}}$ & $83.93 \pm 1.27^{\mathrm{B}}$ & $83.36 \pm 1.53^{\mathrm{B}}$ \\
\hline 4 & $84.22 \pm 1.41^{\mathrm{aBC}}$ & $86.42 \pm 0.77^{\mathrm{cB}}$ & $85.39 \pm 0.99^{\mathrm{bcBC}}$ & $84.54 \pm 1.54^{\mathrm{abB}}$ \\
\hline 6 & $82.96 \pm 1.17^{\mathrm{abA}}$ & $83.96 \pm 1.95^{\mathrm{bA}}$ & $81.09 \pm 3.90^{\mathrm{aA}}$ & $83.53 \pm 1.23^{\mathrm{bB}}$ \\
\hline 8 & $83.34 \pm 1.09^{\mathrm{bAB}}$ & $83.38 \pm 1.06^{\mathrm{bA}}$ & $81.21 \pm 2.33^{\mathrm{abA}}$ & $79.75 \pm 3.82^{\mathrm{aA}}$ \\
\hline \multicolumn{5}{|c|}{$\mathbf{a}^{*}$} \\
\hline 0 & $-1.14 \pm 0.11^{\mathrm{aA}}$ & $-1.06 \pm 0.05^{\mathrm{aAB}}$ & $-0.54 \pm 0.02^{\mathrm{bA}}$ & $-0.21 \pm 0.08^{\mathrm{cA}}$ \\
\hline 2 & $-1.10 \pm 0.04^{\mathrm{aA}}$ & $-1.18 \pm 0.07^{\mathrm{aA}}$ & $-0.57 \pm 0.081^{\mathrm{bA}}$ & $-0.22 \pm 0.18^{\mathrm{bA}}$ \\
\hline 4 & $-0.93 \pm 0.09^{\mathrm{aB}}$ & $-0.97 \pm 0.067^{\mathrm{aB}}$ & $-0.34 \pm 0.13^{\mathrm{bB}}$ & $0.10 \pm 0.13^{\mathrm{cC}}$ \\
\hline 6 & $-1.08 \pm 0.09^{\mathrm{aA}}$ & $-1.11 \pm 0.16^{\mathrm{aA}}$ & $-0.40 \pm 0.14^{\mathrm{bB}}$ & $-0.10 \pm 0.03^{\mathrm{cB}}$ \\
\hline 8 & $-0.79 \pm 0.08^{\mathrm{aC}}$ & $-0.59 \pm 0.23^{\mathrm{aC}}$ & $-0.01 \pm 0.09^{\mathrm{bC}}$ & $0.29 \pm 0.12^{\mathrm{cD}}$ \\
\hline \multicolumn{5}{|c|}{$\mathbf{b}^{*}$} \\
\hline 0 & $13.29 \pm 0.23^{\mathrm{dC}}$ & $10.90 \pm 0.14^{\mathrm{aC}}$ & $12.07 \pm 0.12^{\mathrm{bC}}$ & $12.39 \pm 0.29^{\mathrm{cB}}$ \\
\hline 2 & $13.13 \pm 0.22^{\mathrm{dBC}}$ & $10.47 \pm 0.33^{\mathrm{aAB}}$ & $11.21 \pm 0.55^{\mathrm{bA}}$ & $12.04 \pm 0.39^{\mathrm{cA}}$ \\
\hline 4 & $12.89 \pm 0.19^{\mathrm{dB}}$ & $10.55 \pm 0.18^{\mathrm{aB}}$ & $11.58 \pm 0.20^{\mathrm{bB}}$ & $12.43 \pm 0.21^{\mathrm{cB}}$ \\
\hline 6 & $12.24 \pm 0.50^{\mathrm{cA}}$ & $10.35 \pm 0.10^{\mathrm{aA}}$ & $11.23 \pm 0.45^{\mathrm{bA}}$ & $11.94 \pm 0.35^{\mathrm{cA}}$ \\
\hline 8 & $12.45 \pm 0.41^{\mathrm{dA}}$ & $10.79 \pm 0.21^{\mathrm{aC}}$ & $11.36 \pm 0.43^{\mathrm{bAB}}$ & $12.11 \pm 0.26^{\mathrm{cA}}$ \\
\hline
\end{tabular}

MC - control mayonnaise;

MBHT - mayonnaise made with $0.1 \%$ BHT addition;

MSB3 - mayonnaise made with 3\% sea buckthorn juice addition;

MSB6 - mayonnaise made with $6 \%$ sea buckthorn juice addition;

$\mathrm{L}^{*}$ - lightness color coordinate, $\mathrm{a}^{*}$ - redness/greenness color coordinate;

$\mathrm{b}^{*}$ - yellowness/blueness color coordinate;

Different lowercase letters indicate significant difference at $\mathrm{p}<0.05$ level between different formulations, while different uppercase letters are indicative of the same within each formulation during the storage period; Data are expressed as mean \pm standard deviation.

The darkening of mayonnaise samples during storage may be attributed to the nonenzymatic browning reactions having as substrate the carbonyl compounds generated during lipid oxidation, as well as to the brown-colored oxypolymers produced via polymerization from the lipid oxidation derivatives [34].

Titratable acidity, pH, peroxide values and thiobarbituric acid reactive substances values of mayonnaise

The $\mathrm{pH}$ and titratable acidity of soy milk mayonnaise samples recorded during 8 weeks of storage are given in Table 3 . The mean $\mathrm{pH}$ value was 4.57 in the freshly prepared control 
mayonnaise samples. Addition of sea buckthorn juice determined a significant decrease of the $\mathrm{pH}$ value and an increase of the titratable acidity but the differences between samples within each formulation during the storage period were not significant.

The peroxide value (PV) determines the primary oxidation products (hydroperoxides) formed during the autoxidation of unsaturated lipids and it is an indicator of the initial stage of lipid oxidation or oxidative rancidity [35]. The peroxide values of control and experimental mayonnaise samples during 8 weeks storage are presented in Table 3.

Table 3

Effect of storage on $\mathrm{pH}$, titratable acidity, peroxide values and thiobarbituric acid reactive substances of mayonnaise samples

\begin{tabular}{|c|c|c|c|c|}
\hline Time (weeks) & MC & МBHT & MSB3 & MSB6 \\
\hline \multicolumn{5}{|c|}{$\mathrm{pH}$} \\
\hline 0 & $4.57 \pm 0.15^{\mathrm{bc}}$ & $4.64 \pm 0.11^{\mathrm{c}}$ & $4.30 \pm 0.14^{\mathrm{ab}}$ & $4.04 \pm 0.17^{\mathrm{a}}$ \\
\hline 2 & $4.63 \pm 0.21^{\mathrm{b}}$ & $4.65 \pm 0.19^{\mathrm{b}}$ & $4.29 \pm 0.16^{\mathrm{ab}}$ & $4.03 \pm 0.22^{\mathrm{a}}$ \\
\hline 4 & $4.65 \pm 0.18^{b}$ & $4.69 \pm 0.22^{\mathrm{b}}$ & $4.34 \pm 0.20^{\mathrm{ab}}$ & $4.09 \pm 0.21^{\mathrm{a}}$ \\
\hline 6 & $4.65 \pm 0.24^{\mathrm{b}}$ & $4.72 \pm 0.16^{\mathrm{b}}$ & $4.35 \pm 0.25^{\mathrm{ab}}$ & $4.12 \pm 0.16^{\mathrm{a}}$ \\
\hline 8 & $4.62 \pm 0.20^{b}$ & $4.75 \pm 0.19^{b}$ & $4.41 \pm 0.21^{\mathrm{ab}}$ & $4.21 \pm 0.19^{\mathrm{a}}$ \\
\hline \multicolumn{5}{|c|}{ Titratable acidity } \\
\hline 0 & $0.14 \pm 0.02^{\mathrm{ab}}$ & $0.11 \pm 0.01^{\mathrm{a}}$ & $0.15 \pm 0.02^{\mathrm{bc}}$ & $0.18 \pm 0.02^{\mathrm{c}}$ \\
\hline 2 & $0.13 \pm 0.01^{\mathrm{ab}}$ & $0.11 \pm 0.01^{\mathrm{a}}$ & $0.15 \pm 0.01^{\mathrm{b}}$ & $0.18 \pm 0.02^{\mathrm{c}}$ \\
\hline 4 & $0.13 \pm 0.02^{b}$ & $0.10 \pm 0.01^{\mathrm{a}}$ & $0.14 \pm 0.02^{\mathrm{b}}$ & $0.18 \pm 0.01^{\mathrm{c}}$ \\
\hline 6 & $0.13 \pm 0.01^{b}$ & $0.10 \pm 0.01^{\mathrm{a}}$ & $0.14 \pm 0.01^{\mathrm{b}}$ & $0.17 \pm 0.01^{\mathrm{c}}$ \\
\hline 8 & $0.12 \pm 0.01^{\mathrm{b}}$ & $0.08 \pm 0.01^{\mathrm{a}}$ & $0.14 \pm 0.01^{\mathrm{b}}$ & $0.17 \pm 0.02^{\mathrm{c}}$ \\
\hline \multicolumn{5}{|c|}{ Peroxide values (meq $\cdot \mathrm{kg}^{-1}$ ) } \\
\hline 0 & $2.44 \pm 0.16^{\mathrm{aA}}$ & $2.20 \pm 0.13^{\mathrm{aA}}$ & $2.25 \pm 0.14^{\mathrm{aA}}$ & $2.23 \pm 0.15^{\mathrm{aA}}$ \\
\hline 2 & $7.42 \pm 0.32^{\mathrm{bB}}$ & $5.85 \pm 0.27^{\mathrm{aB}}$ & $6.21 \pm 0.28^{\mathrm{aB}}$ & $6.35 \pm 0.35^{\mathrm{aB}}$ \\
\hline 4 & $17.60 \pm 0.82^{\mathrm{cC}}$ & $7.40 \pm 0.38^{\mathrm{aC}}$ & $8.48 \pm 0.37^{\mathrm{bC}}$ & $8.80 \pm 0.49^{\mathrm{bC}}$ \\
\hline 6 & $26.12 \pm 1.24^{\mathrm{bD}}$ & $11.42 \pm 0.57^{\mathrm{aD}}$ & $11.60 \pm 0.52^{\mathrm{aD}}$ & $11.84 \pm 0.58^{\mathrm{aD}}$ \\
\hline 8 & $34.20 \pm 1.66^{\mathrm{bE}}$ & $12.25 \pm 0.67^{\mathrm{aE}}$ & $12.45 \pm 0.58^{\mathrm{aE}}$ & $12.80 \pm 0.56^{\mathrm{aE}}$ \\
\hline \multicolumn{5}{|c|}{ TBARS values $\left(\mathrm{mg} \cdot \mathrm{kg}^{-1}\right)$} \\
\hline 0 & $0.71 \pm 0.04^{\mathrm{aA}}$ & $0.69 \pm 0.04^{\mathrm{aA}}$ & $0.71 \pm 0.04^{\mathrm{aA}}$ & $0.73 \pm 0.03^{\mathrm{aA}}$ \\
\hline 2 & $0.82 \pm 0.04^{\mathrm{bcA}}$ & $0.72 \pm 0.04^{\mathrm{aA}}$ & $0.75 \pm 0.05^{\mathrm{abA}}$ & $0.85 \pm 0.04^{\mathrm{cB}}$ \\
\hline 4 & $0.99 \pm 0.04^{\mathrm{bB}}$ & $0.82 \pm 0.04^{\mathrm{aB}}$ & $0.93 \pm 0.05^{\mathrm{bB}}$ & $0.94 \pm 0.04^{\mathrm{bB}}$ \\
\hline 6 & $1.45 \pm 0.08^{\mathrm{bC}}$ & $0.97 \pm 0.05^{\mathrm{aC}}$ & $1.05 \pm 0.06^{\mathrm{aC}}$ & $1.35 \pm 0.07^{\mathrm{bC}}$ \\
\hline 8 & $2.18 \pm 0.11^{\mathrm{dD}}$ & $1.18 \pm 0.05^{\mathrm{aD}}$ & $1.35 \pm 0.07^{\mathrm{bD}}$ & $1.87 \pm 0.10^{\mathrm{cD}}$ \\
\hline
\end{tabular}

$\mathrm{MC}$ - control mayonnaise;

MBHT - mayonnaise made with $0.1 \%$ BHT addition;

MSB3 - mayonnaise made with 3\% sea buckthorn juice addition;

MSB6 - mayonnaise made with $6 \%$ sea buckthorn juice addition;

TBARS - thiobarbituric acid reactive substances;

Different lowercase letters indicate significant difference at $p<0.05$ level between different formulations, while different uppercase letters are indicative of the same within each formulation during the storage period; Data are expressed as mean \pm standard deviation. 
After preparing the mayonnaises (day 0), the highest PV value was found in control samples $(2.44 \mathrm{meq} / \mathrm{kg})$. However, no significant differences were found between PV values of mayonnaise samples at this moment. ANOVA indicated a significant $(\mathrm{p}<0.05)$ increase in the PV value of mayonnaise with storage. The results confirmed the previous finding that PV increased gradually in control and experimental mayonnaise samples throughout the storage period [36,37]. As can be seen in Table 3, control mayonnaise showed the highest PV both after 4 weeks $(17.60 \mathrm{meq} / \mathrm{kg})$ and at the end of storage $(34.20 \mathrm{meq} / \mathrm{kg})$.

The results showed that BHT retarded the hydroperoxide formation significantly $(p<0.05)$ in mayonnaise throughout 8 weeks of storage, indicating the high efficiency of BHT in retarding lipid oxidation. Peroxide values of MSB3 and MSB6 samples were lower compared to the control sample but the lowest PV values were recorded in MBHT samples (Table 3).

No significant differences were found between peroxide values of MSB3 and MSB6 samples during the storage period.

The results of the secondary lipid oxidation products as shown by the TBARS values are presented in Table 3. Storage time had a significant effect on mayonnaise oxidation, an increasing level of TBARS was observed in all samples over the storage period, indicating an increase in lipid oxidation during storage. The greatest increase in TBARS values was observed in control mayonnaise samples, followed by MSB6 and MSB3 samples while the lowest was recorded in MBHT samples.

The TBARS values in MSB3 and MSB6 samples were significantly lower $(\mathrm{p}<0.05)$ than in control samples in the last 4 weeks of storage, thus indicating the protective effect of antioxidants extracted from sea-buckthorn juice against lipid oxidation in mayonnaise. However, the strongest protective effect was observed for BHT.

Raikos et al. [15] found that carotenoids did not offer any protection against lipid oxidation, although significant amounts of $\alpha$ - and $\beta$ - carotene and lutein/zeaxanthin were detected in the mayonnaise samples containing carrot, broccoli and onion. Kiokias et al. [38] showed that carotenoid concentration may affect, alongside carotenoid and emulsion structure, the carotenoid activity in sunflower oil-in-water emulsions. They found that several carotenoid extracts (paprika, annatto and marigold preparations) containing mainly polar carotenoids, added at an active concentration of $1 \mathrm{~g} / \mathrm{l}$, exerted a strong activity against hydroperoxides and TBARS during the accelerated oxidation $\left(60^{\circ} \mathrm{C}\right)$ of homogenised protein-based emulsions. On the contrary, carotene preparations rich in hydrophobic $\alpha$ - and $\beta$-carotenes and lycopene did not significantly differ from the control emulsion. Therefore, the carotenoid structure modulated their antioxidant effect, while concentration and emulsion structure may also affect carotenoid activity in protein dispersed systems.

\section{Sensory attributes of mayonnaise}

The results of the sensory analysis of the mayonnaise samples after preparation as well as after 2, 4, 6 and 8 weeks of storage at $4{ }^{\circ} \mathrm{C}$ are shown in Table 4. Except for color, the sensory attributes of MC, MBHT, MSB3 and MSB6 samples did not differ significantly $(p<0.05)$ at zero time, showing that the addition of sea buckthorn juice did not significantly influenced the taste, consistency and the overall acceptability of mayonnaise. A significant decline in all sensory attributes and overall acceptability of mayonnaise was observed during storage. A similar trend for color, aroma, taste, and overall acceptability were observed during the storage of control and lycopene-added mayonnaise [36].

In terms of color, the highest score was recorded for MSB3 sample throughout the storage period, proving that the more reddish color of the mayonnaise due to the addition of 


\section{- Food Technology —}

$3 \%$ sea-buckthorn juice was appreciated by the panelists. However, the deep-reddish color of MSB6 samples was less appreciated and, as a result, the overall acceptability of these samples was lower. In the last part of the storage period (the last 3 weeks) there was a process of syneresis in the samples with added sea buckthorn juice, stronger in samples with $6 \%$ addition. This phenomenon is probably due to the higher acidity values and it explains the decrease of the scores regarding consistency and general acceptability of the MSB3 and MSB6 samples as compared with control and MBHT samples.

Table 4

Effect of storage on sensory attributes of mayonnaise samples

\begin{tabular}{|l|c|c|c|c|}
\hline Time (weeks) & MC & MBHT & MSB3 & MSB6 \\
\hline \multicolumn{5}{|c|}{ Color } \\
\hline 0 & $8.17 \pm 0.39^{\mathrm{aE}}$ & $7.92 \pm 0.51^{\mathrm{aC}}$ & $8.58 \pm 0.51^{\mathrm{bD}}$ & $8.25 \pm 0.45^{\mathrm{abD}}$ \\
\hline 2 & $7.75 \pm 0.45^{\mathrm{aD}}$ & $7.67 \pm 0.49^{\mathrm{aBC}}$ & $8.25 \pm 0.45^{\mathrm{bCD}}$ & $7.83 \pm 0.39^{\mathrm{aC}}$ \\
\hline 4 & $6.75 \pm 0.62^{\mathrm{aC}}$ & $7.25 \pm 0.45^{\mathrm{bAB}}$ & $7.92 \pm 0.51^{\mathrm{cBC}}$ & $7.00 \pm 0.43^{\mathrm{abB}}$ \\
\hline 6 & $6.25 \pm 0.45^{\mathrm{aB}}$ & $7.17 \pm 0.39^{\mathrm{bA}}$ & $7.58 \pm 0.51^{\mathrm{bAB}}$ & $6.58 \pm 0.67^{\mathrm{aA}}$ \\
\hline 8 & $5.83 \pm 0.39^{\mathrm{aA}}$ & $6.83 \pm 0.72^{\mathrm{bA}}$ & $7.17 \pm 0.58^{\mathrm{bA}}$ & $6.25 \pm 0.45^{\mathrm{aA}}$ \\
\hline \multicolumn{5}{|c|}{ Taste } \\
\hline 0 & $8.50 \pm 0.52^{\mathrm{aD}}$ & $8.42 \pm 0.51^{\mathrm{aD}}$ & $8.58 \pm 0.51^{\mathrm{aD}}$ & $8.17 \pm 0.58^{\mathrm{aD}}$ \\
\hline 2 & $8.25 \pm 0.45^{\mathrm{abD}}$ & $8.25 \pm 0.45^{\mathrm{abD}}$ & $8.42 \pm 0.51^{\mathrm{bCD}}$ & $7.92 \pm 0.29^{\mathrm{aCD}}$ \\
\hline 4 & $7.67 \pm 0.49^{\mathrm{abC}}$ & $7.83 \pm 0.39^{\mathrm{abC}}$ & $8.00 \pm 0.43^{\mathrm{bC}}$ & $7.58 \pm 0.51^{\mathrm{aC}}$ \\
\hline 6 & $6.83 \pm 0.39^{\mathrm{aB}}$ & $7.42 \pm 0.51^{\mathrm{bB}}$ & $7.50 \pm 0.67^{\mathrm{bB}}$ & $6.75 \pm 0.45^{\mathrm{aB}}$ \\
\hline 8 & $5.83 \pm 0.39^{\mathrm{aA}}$ & $6.75 \pm 0.45^{\mathrm{bA}}$ & $6.50 \pm 0.52^{\mathrm{bA}}$ & $5.58 \pm 0.51^{\mathrm{aA}}$ \\
\hline \multicolumn{5}{|c|}{ Consistency } \\
\hline 0 & $8.75 \pm 0.45^{\mathrm{aD}}$ & $8.67 \pm 0.49^{9^{\mathrm{aD}}}$ & $8.83 \pm 0.39^{\mathrm{aD}}$ & $8.50 \pm 0.52^{\mathrm{aD}}$ \\
\hline 2 & $8.58 \pm 0.51^{\mathrm{aD}}$ & $8.50 \pm 0.52^{2 \mathrm{D}}$ & $8.58 \pm 0.51^{\mathrm{aD}}$ & $8.25 \pm 0.62^{\mathrm{aD}}$ \\
\hline 4 & $7.83 \pm 0.39^{\mathrm{aC}}$ & $7.92 \pm 0.51^{\mathrm{aC}}$ & $8.00 \pm 0.60^{\mathrm{aC}}$ & $7.67 \pm 0.65^{\mathrm{aC}}$ \\
\hline 6 & $6.92 \pm 0.29^{\mathrm{bB}}$ & $7.00 \pm 0.43^{\mathrm{bB}}$ & $6.83 \pm 0.58^{\mathrm{bB}}$ & $6.42 \pm 0.51^{\mathrm{aB}}$ \\
\hline 8 & $5.92 \pm 0.51^{\mathrm{bcA}}$ & $6.33 \pm 0.49^{\mathrm{cA}}$ & $5.58 \pm 0.51^{\mathrm{abA}}$ & $5.17 \pm 0.72^{\mathrm{aA}}$ \\
\hline \multicolumn{5}{|c|}{ Overall acceptability } \\
\hline 0 & $8.42 \pm 0.51^{\mathrm{a}}$ & $8.33 \pm 0.49^{9^{\mathrm{a}}}$ & $8.50 \pm 0.52^{\mathrm{aC}}$ & $8.25 \pm 0.62^{\mathrm{aD}}$ \\
\hline 2 & $8.25 \pm 0.45^{\mathrm{aD}}$ & $8.17 \pm 0.39^{\mathrm{aCD}}$ & $8.33 \pm 0.49^{\mathrm{aC}}$ & $8.08 \pm 0.51^{\mathrm{aD}}$ \\
\hline 4 & $7.75 \pm 0.45^{\mathrm{abC}}$ & $7.92 \pm 0.29^{\mathrm{abC}}$ & $8.08 \pm 0.67^{\mathrm{bC}}$ & $7.58 \pm 0.51^{\mathrm{aC}}$ \\
\hline 6 & $7.00 \pm 0.43^{\mathrm{abB}}$ & $7.33 \pm 0.49^{\mathrm{bcB}}$ & $7.50 \pm 0.67^{\mathrm{cB}}$ & $6.58 \pm 0.51^{\mathrm{aB}}$ \\
\hline 8 & $6.33 \pm 0.49^{\mathrm{bA}}$ & $6.75 \pm 0.45^{\mathrm{bA}}$ & $6.42 \pm 0.67^{\mathrm{bA}}$ & $5.67 \pm 0.49^{\mathrm{aA}}$ \\
\hline
\end{tabular}

$\mathrm{MC}$ - control mayonnaise;

MBHT - mayonnaise made with $0.1 \%$ BHT addition;

MSB3 - mayonnaise made with 3\% sea buckthorn juice addition;

MSB6 - mayonnaise made with $6 \%$ sea buckthorn juice addition;

Different lowercase letters indicate significant difference at $\mathrm{p}<0.05$ level between different formulations, while different uppercase letters are indicative of the same within each formulation during the storage period; Data are expressed as mean \pm standard deviation. 


\section{Conclusions}

1. The mayonnaise enriched with carotenoids through sea buckthorn juice addition exhibited a good oxidative stability during 8 weeks of storage as indicated by lower peroxide values and thiobarbituric acid reactive substances values.

2. Evaluation of all sensory attributes showed that mayonnaise made with $3 \%$ sea buckthorn juice addition was the most favourable sample and had the highest scores during 4 weeks of storage. However, there was no significant differences in all attributes among mayonnaise made with 3\% sea buckthorn juice addition and mayonnaise made with $0.1 \%$ BHT addition ( $p>0.05)$. Both after 4 weeks and 8 weeks of storage, the lowest scores were given to the control sample for all the sensory properties, which was probably due to the darkening as well as to the off-flavors and off-odors generated in the deteriorative reactions of lipids that occured during storage. This was in accordance with the higher increase of peroxide values and thiobarbituric acid reactive substances values in this sample, indicating that lipid oxidation proceeded to a greater extent.

3. Besides the nutritional aspects related to the increase of antioxidant content, the addition of sea buckthorn juice led to the improvement of the chromatic characteristics of mayonnaise which may increase consumer attractiveness and confidence.

4. By adding sea-buckthorn juice, a stable and safe vegan mayonnaise can be produced without using synthetic antioxidants.

\section{References}

1. Li C.-Y., Kim H.-W., Li H., Lee D.-C., Rhee H.-I. (2014), Antioxidative effect of purple corn extracts during storage of mayonnaise, Food Chemistry, 152, pp. 592-596.

2. Gorji S.G., Smyth H.E., Sharma M., Fitzgerald M. (2016), Lipid oxidation in mayonnaise and the role of natural antioxidants: a review, Trends in Food Science \& Technology, 56, pp. 88-102.

3. Nikzade V., Tehrani M.M., Saadatmand-Tarzjan M. (2012), Optimization of lowcholesterol-low-fat mayonnaise formulation: effect of using soy milk and some stabilizer by a mixture design approach, Food Hydrocolloids, 28(2), pp. 344-352.

4. Mirzanajafi-Zanjani M., Yousefi M., Ehsani A. (2019), Challenges and approaches for production of a healthy and functional mayonnaise sauce, Food Science and Nutrition, 7(8), pp. 2471-2484.

5. Caubet J.C., Wang J. (2011), Current understanding of egg allergy, Pediatric Clinics of North America, 58(2), pp. 427-443.

6. Miranda J.M., Anton X., Redondo-Valbuena C., Roca-Saavedra P., Rodriguez J.A., Lamas A., Franco C.M., Cepeda A. (2015), Egg and Egg-Derived Foods: Effects on Human Health and Use as Functional Foods, Nutrients, 7, pp. 706-729.

7. Diftis N.G., Biliaderis C.G., Kiosseoglou V.D. (2005), Rheological properties and stability of model salad dressing emulsions prepared with a dry-heated soybean protein isolate-dextran mixture, Food Hydrocolloids, 19(6), pp. 1025-1031.

8. Raikos V., Hayes H., Ni H. (2020), Aquafaba from commercially canned chickpeas as potential egg replacer for the development of vegan mayonnaise: recipe optimisation and storage stability, International Journal of Food Science \& Technology, 55(5), pp. 1935-1942. 
9. Alcorta A., Porta A., Tárrega A., Alvarez M.D., Vaquero M.P. (2021), Foods for PlantBased Diets: Challenges and Innovations, Foods, 10, pp. 293.

10. Friedman M., Brandon D.L. (2001), Nutritional and health benefits of soy proteins, Journal of Agricultural and Food Chemistry, 49(3), pp. 1069-1086.

11. Rayaprolu S.J., Hettiarachchy N.S., Chen P., Kannan A., Mauromostakos A. (2013), Peptides derived from high oleic acid soybean meals inhibit colon, liver, and lung cancer cell growth, Food Research International, 50, pp. 282-288.

12. Söderberg J. (2013), Functional Properties of Legume Proteins Compared to Egg Proteins and Their Potential as Egg Replacers in Vegan Food, Swedish University of Agricultural Sciences, Uppsala, Sweden.

13. Puppo M.C., Sorgentini D.A., Añón M.C. (2003), Rheological properties of emulsions containing modified soy protein isolates, Journal of the American Oil Chemists' Society, 80(6), pp. 605-611.

14. Garcia B.G., Sanchez R., Jose L., Villavicencio D., Nunez M. (2002), Influence of formulation in the stability of dressing-type mayonnaise, Alimentaria, 39(338), pp. 8790.

15. Raikos V., Neacsu M., Morrice P., Duthie G. (2015), Anti- and prooxidative effect of fresh and freeze-dried vegetables during storage of mayonnaise, Journal of Food Science and Technology, 52, pp. 7914-7923.

16. Alemán M., Bou R., Guardiola F., Durand E., Villeneuve P., Jacobsen C., Sørensen A.D.M. (2015), Antioxidative effect of lipophilized caffeic acid in fish oil enriched mayonnaise and milk, Food Chemistry, 167, pp. 236-244.

17. McClements D.J., Decker E.A. (2000), Lipid oxidation in oil-in-water emulsions: Impact of molecular environment on chemical reactions in heterogeneous food systems, Journal of Food Science, 65(8), pp. 1270-1282.

18. Mozafari H.R., Hosseini E., Hojjatoleslamy M., Mohebbi G.H., Jannati N. (2017), Optimization low-fat and low cholesterol mayonnaise production by central composite design, Journal of Food Science and Technology, 54(3), pp. 591-600.

19. Ruan C.-J., da Silva J.A.T., Jin H., Li H., Li D.-Q. (2007), Research and biotechnology in sea buckthorn (Hippophae spp.), Medicinal and Aromatic Plant Science and Biotechnology, 1(1), pp. 47-60.

20. Bal L.M., Meda V., Naik S.N., Satya S. (2011), Sea buckthorn berries: a potential source of valuable nutrients for neutraceuticals and cosmoceuticals, Food Research International, 44, pp. 1718-1727.

21. Nour V., Panaite T.D., Corbu A.R., Ropota M., Turcu R.P. (2021), Nutritional and bioactive compounds in dried sea-buckthorn pomace, Erwerbs-Obstbau, 63, pp. 91-98.

22. Kim J.-S., Kwon Y.-S., Sa Y.-J., Kim M.-J. (2011), Isolation and identification of sea buckthorn (Hippophae rhamnoides) phenolics with antioxidant activity and aglucosidase inhibitory effect, Journal of Agricultural and Food Chemistry, 59(1), pp. $138-144$.

23. Kashyap P., Deepshikha Riar C.S., Jindal N. (2020), Sea Buckthorn, In: Nayik G.A., Gull A. (eds.) Antioxidants in Fruits: Properties and Health Benefits, Springer, Singapore.

24. Lee H.S. (2001), Characterization of carotenoids in juice of red navel orange (Cara Cara), Journal of Agricultural and Food Chemistry, 49, pp. 2563-2568.

25. AOAC (1984), Official Methods of Analysis (14th edition), Association of Analytical Chemists, Washington D.C.

26. AOAC (2000), Official Methods of Analysis (17th edition), Association of Analytical Chemists, Washington D.C. 
27. Witte V.C., Krauze G.F., Bailey M.E. (1970), A new extraction method for determining 2-thiobarbituric acid values of pork and beef during storage, Journal of Food Science, 35 , pp. 582-585.

28. Oomah B.D., Sery G., Godfrey D.V. (1999), Rheology of sea buckthorn (H. rhamnoides L) juice, Journal of Agricultural and Food Chemistry, 47, pp. 3546-3550.

29. Beveridge T., Harrison J.E., Drover J. (2002), Processing effects on the composition of sea buckthorn juice from Hippophae rhamnoides L. cv. Indian Summer, Journal of Agricultural and Food Chemistry, 50, pp. 113-115.

30. Zeb A. (2004), Chemical and nutritional constituents of sea buckthorn juice, Pakistan Journal of Nutrition, 3(2), pp. 99-106.

31. Seglina D., Karklina D., Ruisa S., Krasnova I. (2006), The effect of processing on the composition of sea buckthorn juice, Journal of Fruit and Ornamental Plant Research, 14(2), pp. 257-264.

32. Jeppsson N., Gao X.Q. (2000), Changes in the contents of kaempherol, quercetin and L-ascorbic acid in sea buckthorn berries during maturation, Agri. Food Sci. Finland, 9, pp. 17-22.

33. Altunkaya A., Hedegaard R.V., Harholt J., Brimer L., Gökmen V., Skibsted L.H. (2013), Oxidative stability and chemical safety of mayonnaise enriched with grape seed extract, Food and Function, 4, pp. 1647-1653.

34. Villamiel M., del Castillo D., Corzo N. (2006), Browning reactions. In Hui Y.H., Nip W.-K., Nollet L.M.L., Paliyath G., \& Simpson B.K. (eds.), Food biochemistry and food processing (1st ed.), Oxford, UK: Blackwell, pp. 71-100.

35. Ahmadi-Dastgerdi A., Ezzatpanah H., Asgary S., Dokhani S.H., Rahimi E., GholamiAhangaran M. (2019), Oxidative stability of mayonnaise supplemented with essential oil of Achillea millefolium ssp millefolium during storage, Food Science and Technology, 13(1), pp. 34-42.

36. Kaur D., Wani A.A., Singh D.P., Sogi D.S. (2011), Shelf life enhancement of butter, ice-cream, and mayonnaise by addition of lycopene, International Journal of Food Properties, 14(6), pp. 1217-1231.

37. Gomes A., Costa A.L.R., de Assis Perrechil F., da Cunha R.L. (2016), Role of phases composition on the incorporation of gallic acid in $\mathrm{O} / \mathrm{W}$ and $\mathrm{W} / \mathrm{O}$ emulsions, Journal of Food Engineering, 168, pp. 205-214.

38. Kiokias S., Varzakas T., Arvanitoyiannis I., Labropoulos A. (2010), Lipid oxidation and control of oxidation. In: Yildiz F. (ed.), Advances in food biochemistry. Boca Raton: Taylor and Francis Group, CRC Press, pp. 383-409. 